Journal of Urban and Regional Analysis, vol. VIII, 1, 2016, p. 47 - 60

\title{
GOVERNANCE, URBAN COMPETITIVENESS AND CRISIS IN SPAIN
}

\author{
Xosé SOMOZA MEDINA \\ University of León, Spain
}

\begin{abstract}
This article describes the rise of the term governance from its beginnings in the business world and the neoliberal economic thought through its application in urban renewal actions in the world's major cities. Over the analysis, we argue that it was the theoretical discourse of urban governance and competitiveness that for decades enabled the private property sector to direct the urban regeneration processes of greatest added value. Changes in transport infrastructures and the abandonment of old industrial facilities left large central segments of the city available for redevelopment in line with the theories of post-Fordist capitalism. The global economic crisis has paralysed many of these projects, which had entailed the investment of large sums of public money and yielded low social returns. At the same time, criticism has been levelled against governance and strategic planning. Here, I examine the processes of governance and competitiveness as an urban objective and recent examples of urban renewal in Spanish cities.
\end{abstract}

Key Words: governance, strategic planning, competitiveness, urban renewal.

\section{Introduction}

Many cities in developed countries have witnessed urban renewal processes in recent decades, but in Spain the phenomenon has spread to the entire urban system. These types of action are usually promoted by public-private consortia whose partners seek different objectives: public entities aim to improve an area of the city in crisis, while private entities hope to obtain the greatest possible financial return, all within systems of urban governance in a context of competitiveness (Harvey 1989, Swyngedouw 2005, Alcalá-Santaella et al. 2011).

Urban planning, too stringent for these speculative interests, did not offer a satisfactory regulatory instrument and thus a new, more flexible and ambitious model was launched, known as strategic planning. The aim of this new approach was to promote public-private partnerships that combined the interests of the public and private sectors. This was an ambitious goal seeing that the public authority sought to achieve social returns and the private investors to maximise profits (Asworth and Voogd 1990, Swyngedouw 2005). The challenge was to merge both positions in order to increase residents' quality of life; however, rather than "socialising" private sector's objectives, cities became converts to the tenets of business.

Thus, the renewal of cities was guided by two other theoretical discourses from the world of business: enhancing competitiveness and marketing (Ashworth and Voogd 1990). Mayors were expected to think like company managers, defining business models, studying how to become more competitive and creating marketing campaigns to rebrand their product.

In the urban transformation projects launched in the United States in the 1980s (but which subsequently spread to the rest of the developed world), renewal was promoted in a given central area, which became the site of a new emblematic feature with an avant-garde design that aspired to become the symbol of the new 21 st century city. Renewal projects seek to catalyse a broader economic revitalisation process that will extend throughout the city; 
however, the first consequence is an increase in house prices in the surrounding residential area, and gentrification. In effect, public investment paves the way for private profit and social exclusivity (Harvey 1989).

The first city in Spain to adopt this model was Barcelona; not in vain had the city organised the first meeting of American and European cities in 1993 to exchange experiences of strategic planning, with a formidable list of participating institutions, including the World Bank, the Inter-American Development Bank and the European Commission. Nonetheless, with the renovation of the Nervión estuary and the inauguration of the Guggenheim Museum in 1997, it was Bilbao that proved the definitive spur to widespread the adoption in Spain of the cultural tourism model of urban renewal, a local variable that brings together tourism, property speculation, international architecture and high cost overruns (Somoza Medina 2013).

\section{Governance, strategic plans and urban competitiveness}

The term "governance" began to spread at the end of the 1970s in relation to the policies, management and internal administration of private enterprise (corporate governance), and it was used by neoliberal schools advocating the extension of economics methods to the rest of the social sciences (García 2009). Later, the term was used by the Institute for International Economics think tank, responsible for promoting the so-called Washington Consensus that in turn prompted the World Bank and the International Monetary Fund to stop lending to poor countries unless they established systems of governance, i.e. new methods of government characterised by effectiveness and efficiency, which reduced spending by implementing social cuts. Since then, the strategies for combating poverty adopted by these international bodies have involved intervention in the national economies of recipient countries, imposing severe economic adjustment programmes. In referring to better governance in the November 1989 report on sub-Saharan Africa, the World Bank linked governance directly to development, as did the OECD shortly afterwards (Rojo Salgado 2009).

In the 1990s, the United Nations Development Programme (UNDP) softened the term by speaking instead of "good" governance, which would be generated by demanding less state intervention in channelling financial assistance to undeveloped countries and greater participation of "civil society". This would reduce excessive verticality in international cooperation models and facilitate horizontality, introducing the private sector and the third sector into decision-making processes in collaboration with the public sector.

In 2001, it was the turn of the European Commission to designate governance as the ideal operational model for Community institutions, and by extension, all other local, regional, state and international public institutions. The white paper defined European governance as the regulations, processes and behaviours that affect the exercise of authority at European level, particularly from the point of view of openness, participation, responsibility, efficiency and coherence (European Commission 2001).

Jan Kooiman (1993) has stated that the only way to govern dynamic, diverse and complex socio-political systems democratically and effectively is to incorporate the dynamism, diversity and complexity of our societies. Cultural, political and economic globalisation, the new postmodern society, the crisis, in sum the troubled world in which humans have lived since the end of the 20th century all seem to lead inexorably to the need for a new system of government, called governance, in which the owners of capital no longer need to hide behind politicians but can stand right beside them and guide public policy. In the words of Enrique Conejero Paz (2005), governance emerged in a scenario of institutional fragmentation, a network of complex public policies, and nebulous boundaries between the public sector, the private sector and civil society. Some authors even speak of governance without government (Rosenau and Czempiel 1992, Rhodes 1996) (think of the case of Greece or Italy), or of the 
democratic legitimacy of governance (Martínez Brouchoud 2010).

The increasing complexity of urban policies and public management has changed the traditional formulas of urban government, ushering in the spread of the term "urban governance" (Rodríguez et al. 2001, Blanco and Subirats 2012). Cities are governed by structural relationships between traditional organs of local government, private sector institutions and associations, NGOs and citizens. Following a productivist model and guided by the criteria of efficiency in the provision of services and the subordination of redistributive social objectives to the imperatives of competitiveness and the promotion of economic growth, urban governance fosters decentralisation and the fragmentation of responsibilities (Jessop 1997, Swyngedouw 2005).

Governance, therefore, is a polysemic and ideological concept of neoliberal origin which is aimed at normalising the creation of public-private partnerships responsible for directing the policies, projects and management of democratic institutions (García 2009). This model has been gradually adopted by political institutions in a hierarchy from greater to lesser complexity, from global relations between the rich and poor countries, through supranational continental agencies, to central, regional and local government, first in the large cities and then in the rest. There has been a similar shift from territorial governance to urban governance, physically visible in the renewal processes that have taken place in major cities over the past three decades.

Architects and geographers have analysed the transformations brought on cities around the world since the pioneering examples in the 1980s. Large-scale urban intervention in empty spaces in cities began in the United States in places such as Baltimore, Cleveland and Pittsburgh, and later spread to the rest of the world, and cases have been studied in numerous cities (Davies and Townshend 2002, Pacione 2004, Pack 2004, Murayama and Du 2005, Lois González 2006, O'Donoghue 2014). In all of them, interventions have been linked to strategies aimed at rebranding and promoting the city in question, in a bid to boost urban competitiveness and to attract future investment.

The model was almost always the same: urban interventions were carried out in decaying areas that had been abandoned due to industrial decline, decentralisation and productive restructuring or changes in the major transport infrastructures, in order to create appealing spaces that were attractive to the market, a new and exclusive urban area which was supposed to represent the entirety of the city's image in the 21st century (Etulain 2008). In order to create new focal points, these urban projects have combined productive, residential, commercial, cultural and leisure uses and have incorporated a series of recurrent features designed along the same lines: emblematic buildings, the conversion of public space into spectacle, conference centres, cultural and tourism infrastructures, theme parks, festivals and other international events, all with the same goal of urban promotion and marketing (Somoza Medina 2013).

Major interventions were always initially advertised as self-financing projects that would generate income through rising land prices and the consequent contribution from large companies in the property sector. In reality, however, such projects usually incurred significant cost overruns that were met by local, regional and central government, but never by the construction companies that were the real beneficiaries of the venture (Somoza Medina 2013).

As long ago as 1989, David Harvey levelled criticism at these large urban projects because they employed direct public investment and fiscal and financial incentives to stimulate private investment, evidencing the change of direction in planning priorities and urban policies, which were now marked by the rise of a post-Keynesian style of government that embraced a corporate approach through the adoption of business methods by government institutions. As a 
result, large cities were managed as if they were businesses, and rather than attending to residents' needs, the goal was to be competitive in the network of international flows (Harvey 1989).

Strategic planning helped consolidate this vision of large urban projects as being the driving and guiding force behind urban development within the framework of a non-sequential, dialectic relationship between objectives, strategies and projects, a model that made it possible to circumvent stringent urban planning criteria and imbue urban government with the language and ideology of business. This strategic reorientation towards corporate urbanism thus assumed the existence of competition between cities, and consequently pursued competitive advantages in an attempt to project the image of a dynamic, innovative, stimulating and creative city capable of successfully competing to attract new productive investments and consumers, whether tourists or new residents (Swyngedouw 2005).

The paradox is that the recurrent repetition of the same instruments and artefacts, from architectural design and the choice of "starchitects" to promotional slogans, reintroduced uniformity and non-differentiation among what were intended to be exclusive flagship projects. Rather than enhancing differences, these projects wound up creating similar landscapes (Harvey 1989).

Attempts to address the growth crisis cities faced in the late 20th century were based on creating new combinations of economic factors that would render them more competitive, and such approaches were termed "urban entrepreneurialism", "corporatism", "entrepreneurship" or simply "governance" (Jessop 1997, Hall and Hubbard 1998, Jouve 2005).

The new urban agenda adopted a proactive, dynamic and entrepreneurial style, seeking opportunities where the public and the private sectors could undertake joint actions, and the term "competitiveness" was widely and excessively reiterated to justify large investments that lacked proper planning or a detailed analysis of their real future impact (Lois González 2010).

The rhetoric of competitiveness prompted local authorities to embrace a policy of attracting external investment rather than focusing on enhancing their own resources (González 2007). The new urban policies reflected the priority given to urban growth and regeneration while subordinating social objectives to the logic of competitiveness. As neoliberalism spread, large cities began to be guided solely by this criterion (Somoza Medina 2007), resulting in transformations that some urban scholars have described as the creative destruction of the neoliberal city (Theodore et al. 2009). The goal of local corporations was to enhance the city's capacity to successfully face global competition, but this became a never-ending task.

These approaches were modified by the economic crisis that erupted in 2007 in the United States and had become global by 2008. Large urban projects slowed down or were struck off the agenda, and paradigms other than governance took a centre stage. Concepts such as the creative city, smart city, shrinking city, citta slow or urban resilience began to dominate the academic and political urban scene (Méndez 2012).

\section{Urban renewal projects in Spain. The spread of the "Guggenheim effect"}

In Spain, there are two models of successful urban renewal that have served as the mirror in which all other cities wished to see themselves reflected. The renovation of Bilbao's image with the inauguration of the Guggenheim Museum (1997), and the Olympic Barcelona's new maritime front (1992) and forum (2004), created a delusory vision of Spain at the turn of the century.

In a favourable economic and financial climate, public-private governance and strategic 
planning of large investments and new symbols of both cities created sufficient impetus to reinvent them. However, the passage of time has revealed glimpses into the darker side of these projects and several criticisms have targeted both Bilbao's Guggenheim model (Rodríguez 2001, Vicario and Martínez Monje 2003, González Ceballos 2004, Plaza et al. 2010, Mas Serra 2011) and the Barcelona model (Capel 2005, Casellas 2006, Delgado 2007, Blanco Fillola 2009, Borja 2009). These studies have called into question the gains achieved in recent years from urban renewal and governance in both cities, claiming that the main beneficiaries of huge public investments disbursed at different levels of government in order to "reinvent" Barcelona and Bilbao were the interests of capital and especially the property sector, while the majority of residents became the victims of spatial segregation due to soaring prices.

In spite of this, the other major Spanish cities attempted to copy these models. Valencia completely renovated a former slum to create the City of Arts and Sciences, designed by the architect Santiago Calatrava; Zaragoza reinvented itself with the Expo 2008 World Fair and a series of new buildings and infrastructures in the Ebro valley; while Seville's star project was the construction of the Isla Mágica theme park on the site of the Expo 1992 World Fair. Meanwhile, Madrid unveiled a new skyline in 2008 punctuated by the four towers of the CTBA business district, built on the site of Real Madrid's former training complex, while also projecting a much more ambitious intervention in the same area, around Chamartín railway station.

However, the spread of this model, of converting the city into spectacle, was not limited to big cities, as we can mention other "singular" projects of a similar scale and level of investment as those of the large metropolises, such as the Circus City in Alcorcón, the City of Light in Alicante, the City of the Environment in Soria, the Oscar Niemeyer Cultural Centre in Avilés and the City of Culture in Santiago de Compostela. The flame of the Guggenheim model spread throughout the entire urban system, fanned by property speculators and estate agents with the connivance of local politicians, some corrupt and others simply naive. The same discourse was everywhere believed and applied, and it can be summarised as the need to put the city of " $X$ " on the world map by means of an ambitious project for a new " $Y$ " (airport, conference centre, sports stadium). This vital development would embody the new image of " $X$ " in the 21st century and ensure its definitive international impact in the difficult globalised world of urban competitiveness.

Spain was an atypical case for the proliferation of these "celebrity" urban renewal actions. Each medium and even small-sized city wanted to have its own "Foster", "Hadid", "Eisenman", "Ghery", "Nouvel”, "Koolhaas", "Piano", "Chiperfield", "Isozaki”, “Ito", "Rogers", "Perrault", "Calatrava", "Moneo", "Herzog \& De Meuron" and so on, until completing the list of celebrity architects. These all have works in Spain. Dozens of cities hired leading figures from the international pantheon of architects, regardless of the lack of a functional need for such work, without taking into account the excessive investment involved, and without calculating the subsequent unaffordable maintenance costs (Moix 2010). The pretext of urban competitiveness generated an exorbitant increase in public spending at all levels of government, financed through bank loans. Although apparently contrary to the commandments of effectiveness and efficiency in spending promoted by neoliberal ideology, such extravagance sustained the mirage of urban renewal.

Public spending was so exorbitant that in return for the Spanish bank bailout, Europe demanded a drastic reduction in the public deficit, which by 2009 had reached $11 \%$ of the GDP. Austerity was imposed on the public agenda with sweeping cuts of all kinds, and urban governance was prohibited by law, or more specifically, from December 2013, all local governments in Spain were forbidden to establish new consortia or public-private entities (Government of Spain 2013). However, up until that moment the list of urban renewal projects had continued to lengthen. 


\section{Methodology}

\section{Analysis of interventions of urban renewal in Spain. Selecting Case Studies}

To analyse cases of urban renewal in Spain following the model set by the examples of Barcelona and Bilbao, a study of 20 cities with different characteristics (Table 1) was performed. The differences between the study case cities are in terms of: population size (from Huesca with 50000 inhabitants to Palma de Mallorca with 400000 inhabitants); political and administrative range (capitals of autonomous community as Merida and Pamplona, provincial capitals like Leon and Cordoba, and other medium-sized cities without range of capital as Vigo or Cartagena); and location (coastal cities like A Coruña or Santander, interior cities as Oviedo or Jaen, and island cities such as Tenerife and Palma) (Fig. 1).

Population and characteristics of analysed cities

Table 1

\begin{tabular}{|l|r|c|c|}
\hline City & $\begin{array}{c}\text { 2015 Population } \\
\text { (no. of inhabitants) }\end{array}$ & $\begin{array}{c}\text { Autonomous } \\
\text { Capital }\end{array}$ & $\begin{array}{c}\text { Provincial } \\
\text { Capital }\end{array}$ \\
\hline Palma & 400578 & $\mathrm{X}$ & $\mathrm{X}$ \\
\hline Alicante & 328648 & & $\mathrm{X}$ \\
\hline Córdoba & 327362 & & $\mathrm{X}$ \\
\hline Vigo & 294098 & & $\mathrm{X}$ \\
\hline A Coruña & 243870 & $\mathrm{X}$ & $\mathrm{X}$ \\
\hline Oviedo & 221870 & $\mathrm{X}$ & $\mathrm{X}$ \\
\hline Cartagena & 216971 & $\mathrm{X}$ & $\mathrm{X}$ \\
\hline Tenerife & 203811 & $\mathrm{X}$ & $\mathrm{X}$ \\
\hline Pamplona & 195853 & $\mathrm{X}$ & $\mathrm{X}$ \\
\hline San Sebastián & 186095 & & $\mathrm{X}$ \\
\hline Santander & 173957 & $\mathrm{X}$ & $\mathrm{X}$ \\
\hline Logroño & 151344 & $\mathrm{X}$ & $\mathrm{X}$ \\
\hline Lleida & 138542 & $\mathrm{X}$ & $\mathrm{X}$ \\
\hline León & 127817 & & $\mathrm{X}$ \\
\hline Jaén & 115395 & & $\mathrm{X}$ \\
\hline Toledo & 83226 & & $\mathrm{X}$ \\
\hline Ciudad Real & 74427 & & $\mathrm{X}$ \\
\hline Mérida & 58971 & & $\mathrm{X}$ \\
\hline Cuenca & 55428 & & $\mathrm{X}$ \\
\hline Huesca & 52239 & & $\mathrm{X}$ \\
\hline
\end{tabular}

In selected cities, urban renewal projects of the last twenty years were studied, according to three types of actions. Firstly, the transport infrastructure projects were analysed, including railway stations and new railway layouts with the advent of high speed, the construction or renovation of airports, reforms in ports and boardwalks and building new bus terminals of modern design. Secondly, the projects included the creation of new museums modelled after the Guggenheim in Bilbao, and of cultural containers with spectacular forms localised in strategic places leading gentrification. And thirdly, the building of convention and exhibition centres, with the same characteristics as the previous case, was considered. Once these urban renewal operations were detailed, the creation of new housing neighbourhoods and the process of gentrification in relation to these strategic actions were analysed. 


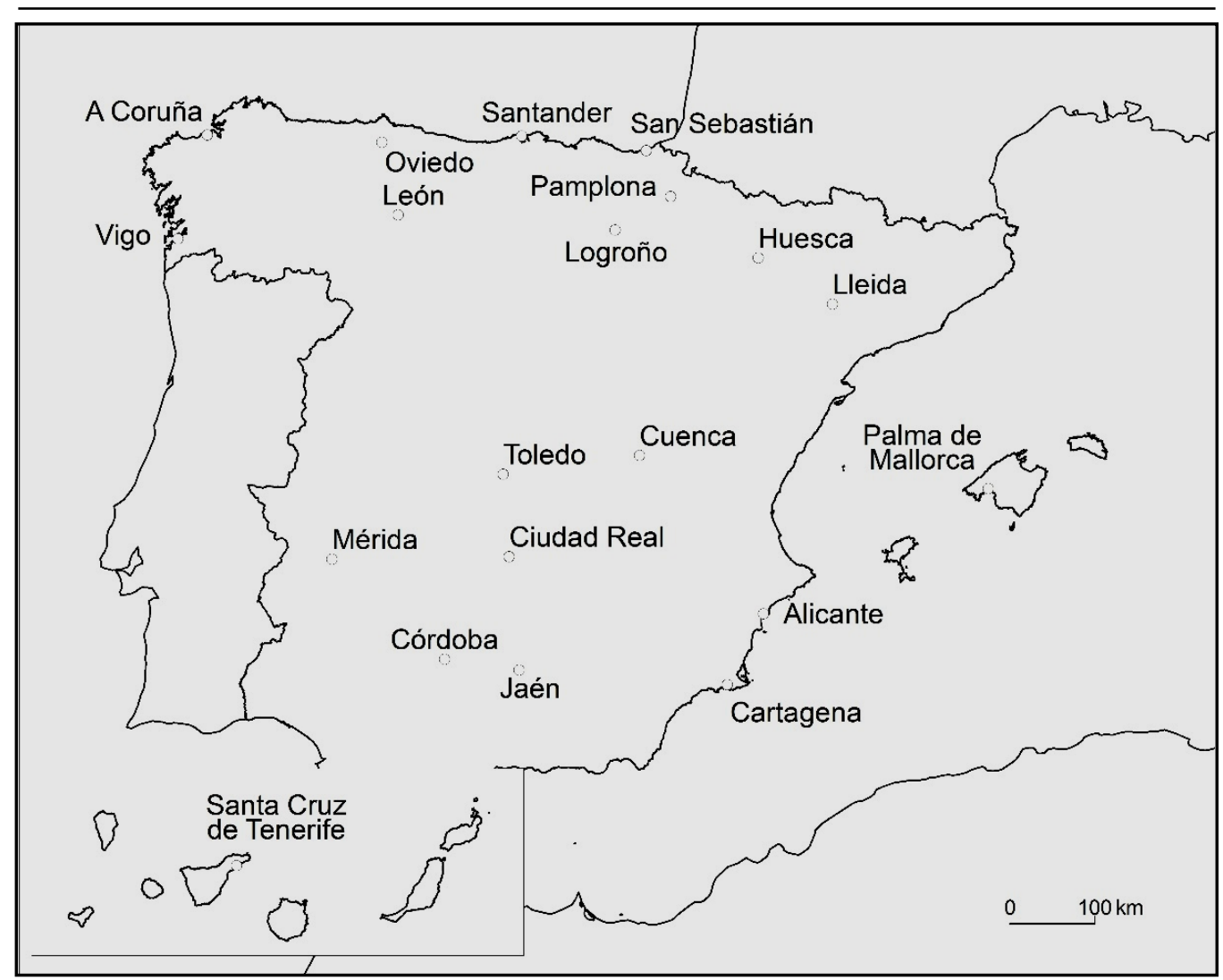

Fig. 1 - Location of the 20 Spanish cities analysed

The analysis of these interventions is reflected in the following table, which shows the extent of the phenomenon on the Spanish geography and the repetition of similar actions (Table 2). Some of the examples of public intervention and new residential areas created are explained in the following paragraphs.

\section{Results and Discussion}

\section{Transport infrastructures}

New transport infrastructures are the responsibility of central government in the case of ports and new high-speed train stations, whereas regional governments have played a major role in constructing or modernising airports with the aim of attracting tourists and creating employment. Spain currently has 46 airports, as many as France and the United Kingdom put together, although passenger volume at 13 of them did not exceed 40000 people in 2015 . The worst case is that of Ciudad Real airport, a private airport promoted by construction firms but with the financial backing of the regional government of Castile-La Mancha, which was aimed at competing with Barajas airport (Madrid), located just over $240 \mathrm{~km}$ away. Following an investment of 1000 million euros, the airport has remained closed since April 2012 and a foreclosure sale is in process, although several auctions have been held without success, the last one with a minimum selling price of 56.2 million euros. 
Urban renewal projects in selected cities

\begin{tabular}{|c|c|c|c|c|}
\hline City & $\begin{array}{c}\text { Transport } \\
\text { Infrastructures }\end{array}$ & Museums & $\begin{array}{c}\text { Convention and } \\
\text { exhibition } \\
\text { centres }\end{array}$ & $\begin{array}{c}\text { Gentrification and } \\
\text { new residential } \\
\text { districts }\end{array}$ \\
\hline Alicante & $\bar{X}$ & $\bar{X}$ & $\mathrm{X}$ & $\mathrm{X}$ \\
\hline Cartagena & & $\bar{X}$ & $\bar{X}$ & \\
\hline Ciudad Real & $\bar{X}$ & $\bar{X}$ & $\bar{X}$ & \\
\hline Córdoba & $\mathrm{X}$ & $X$ & $X$ & $\bar{X}$ \\
\hline Coruña & $\bar{X}$ & $\bar{X}$ & $\bar{X}$ & $\bar{X}$ \\
\hline Cuenca & $\bar{X}$ & $\bar{X}$ & $\bar{X}$ & \\
\hline Huesca & $\mathrm{X}$ & & $\bar{X}$ & \\
\hline Jaén & & $\bar{X}$ & $\frac{2}{x}$ & \\
\hline León & $\mathrm{X}$ & $\bar{X}$ & $\bar{X}$ & $\bar{X}$ \\
\hline Lérida & $\mathrm{X}$ & $\bar{X}$ & $\bar{X}$ & \\
\hline Logroño & $\mathrm{X}$ & $\bar{X}$ & $\bar{X}$ & $\bar{X}$ \\
\hline Mérida & & $\mathrm{X}$ & $\bar{X}$ & \\
\hline Oviedo & $\bar{X}$ & $\bar{X}$ & $\bar{X}$ & $\bar{X}$ \\
\hline Palma & $\mathrm{X}$ & $x$ & $x$ & $x$ \\
\hline Pamplona & $\mathrm{X}$ & $\mathrm{X}$ & $\bar{X}$ & $\bar{X}$ \\
\hline San Sebastián & $\mathrm{X}$ & $X$ & $X$ & $X$ \\
\hline Santander & & $x$ & $\bar{x}$ & $\bar{x}$ \\
\hline Tenerife & $\mathrm{X}$ & & $\bar{X}$ & \\
\hline Toledo & $\bar{X}$ & $\bar{X}$ & $\bar{X}$ & $\bar{X}$ \\
\hline Vigo & $\bar{X}$ & $\bar{X}$ & $\bar{X}$ & \\
\hline
\end{tabular}

Worldwide, Spain ranks second only to China for the number of kilometres of high-speed railway. In recent years, this has enabled many medium-sized cities to replace old railway stations with new, distinctively designed terminals as part of a project to renovate an area that includes the construction of luxury homes to recoup some of the costs, in imitation of the successful model implemented in the 1990s in Seville. In 2016, many of these projects have stalled, because with a stock of hundreds of thousands of empty homes and a stagnant market, the prospect of a self-financing initiative has proved to be a chimera. Such is the case for example of Ourense, where the construction of a new station designed by Norman Foster was supposed to be funded according to this financial model; however, the central government has now denied permission for the project.

\section{Museums}

Attracting cultural tourism is the main goal of the dozens of new museums that have sprung up in recent years in Spain, following directly in the footsteps of the Guggenheim Museum in Bilbao, whereby a feature boasting an avant-garde design is expected to be capable of generating a large influx of new visitors and a contemporary revitalisation of the local economy. Despite the attempts to repeat this model, the proliferation of this type of cultural receptacle has not prompted a substantial change in the economic dynamics of the promoting locations. Museums represent an increase in urban cultural attractions of which the local population mainly benefits, and it is only when they incorporate a series of characteristics related to excellence and uniqueness that they become capable of attracting external flows of any magnitude. Numerous recent examples in Spain include the cases of A Coruña and Jaén.

In A Coruña, a city in Galicia, five new exhibition spaces - three public and two private ones 
- have been opened in recent years, significantly increasing the city's cultural attractions. The refurbished House of Sciences was joined in 1995 by the House of Man, in a building designed by the Japanese architect Aratalsozaki, in 1999 by the Finisterrae Aquarium, in 2003 by the Luis Seoane Foundation, in 2006 by the headquarters of the Abanca Foundation and in 2012 by the National Museum of Science and Technology. What had been launched as a modern and creative but entirely municipal initiative eventually became a dynamic generator of more buildings and new stakeholders. The project to renovate the city included other unique milestones such as the declaration of the Tower of Hercules (the only lighthouse of Roman origin still in use) as a World Heritage Site in 2009 or the complete refurbishment of the seafront.

The museum project in Jaén was first mooted in 2001, when the now ex-mayor announced that the new International Museum of Iberian Art would be larger than the Guggenheim in Bilbao. However, due to various problems, the work did not start until August 2009, when the economic crisis had already paralysed many other initiatives throughout Spain. Located on the central site of the old provincial prison, the construction of the building grounded to a halt in 2012 due to irregularities and lack of funds. More than two years later, at the end of 2014, the work was resumed and the museum is scheduled to open in 2017. Costing 26.3 million euros, the new building will display exactly the same works that can already be seen today in the nearby Provincial Museum.

\section{Convention and exhibition centres}

The primary goal of buildings of this type is to attract what is known as congress tourism, as the capacity of these buildings outstrips by far the local demand. According to official data, 140 convention centres have been opened in Spain by 2012, and 20 more were under construction. One of these which has still not been completed is a convention and exhibition centre in León, designed by the architect Dominique Perrault and built with a budget of 76 million euros. The new building was to retain part of the structure of an old sugar factory in the western sector of the city, revitalised by a high-speed railway infrastructure. The most serious problem with this project is that León has already opened a new auditorium in 2002 with a capacity for 1200 people, which is largely unused for the most part of the year. The works on the new centre began in 2011 with a projected completion date 24 months hence, but the project had to be rescheduled in 2014 due to a lack of public funds.

There are many other conference centres across the length and breadth of Spain as little justified as that in León. Another example is that of Villanueva de la Serena, a town in Extremadura with 26000 inhabitants that has a convention centre which costs 13 million euros and it has a capacity for up to 800 people, even though the town is relatively close to the cities of Badajoz, Mérida and Cáceres, all three with their respective convention centres which together registered only 97 days of operation in 2011.

The convention and exhibition centre of Oviedo was also a project questioned since its inception. Designed by the architect Santiago Calatrava and located on the grounds of a former football field, the initial budget of 76 million euros was overflowed from various setbacks and claims to reach 360 million euros. The area where the new building is located has risen the housing price, driving apart the usual resident population, such as the students from the nearby university campus.

\section{Gentrification and new residential districts}

Neoliberal urban renewal projects are always accompanied by the construction of hundreds of homes in new sectors that have been rehabilitated with public money. This is the economic business spurring public-private partnerships that include the large companies in the property 
sector. Public money is used to create exclusive new sectors with the cooperation and participation of large companies in the sector, which then benefit from the sole management of the resulting residential space, now worth much more than before. Usually, these processes revolve around one of the elements referred to in the preceding paragraphs, but occasionally, the urban renewal process focuses on the housing stock itself, which thus becomes the new flagship for the 21 st century city due to its uniqueness. This process has occurred in a number of medium-sized Spanish cities, including Logroño and Toledo.

In 2006, the Logroño city council convened an international competition for the design of 682 subsidised dwellings, which was won by the Japanese architect Toyo Ito. The winning design resembles a chain of DNA, but the apartments were so small (35 and $56 \mathrm{~m}^{2}$ ) that sales flopped and it was decided to carry out reforms to obtain more spacious dwellings by knocking the apartments together. Thus, a total of 468 dwellings went on sale in 2011; however, five years later and following a $25 \%$ reduction in the price, $65 \%$ of the apartments remain unsold.

The autonomous government of Castilla-La Mancha and the city of Toledo presented in 2008 what would be the "advanced neighbourhood", the new city of the future, designed by the architects Jean Nouvel and Mia Haeg, in which 2000 subsidised dwellings would be built in houses of modern design. In 2011, the project was abandoned by the new governments that emerged after the elections.

In other cities such as Oviedo, Alicante, Leon and Cordoba, the reforms of the railway infrastructure with the arrival of the AVE allowed the existence of free urban land in the central sectors, on which to develop new housing projects of high value. These emerging new neighbourhoods respond to the model of public-private consultation where economic benefits are captured by real estate companies.

In the case of A Coruña and Palma, modern high-level residential quarters have been designed in relation to the creation of new public facilities. While in the case of Pamplona, Santander and San Sebastian, the most striking process has been the gentrification of large central sectors after urban regeneration processes carried out by public initiative, also with stellar landmarks as the convention and exhibition centre of San Sebastian, the new museum of contemporary art in Pamplona, both works of Spanish architect Rafael Moneo, or Botín Foundation Santander Center designed by the Italian architect Renzo Piano.

Of the 20 cities studied, only in 11 of them can be confirmed a direct relationship between the public performances of urban renewal and the new residential districts or gentrified central sectors, generating high economic benefits to the real estate sector. The global economic crisis and, in the case of Spain, the bursting of the housing bubble explain why in almost half of the analysed cities large housing developments have not been generated inside their urban renewal operations. In fact, in some cities, the demand for new housing was reduced even before the outbreak of the crisis, so the economic benefit for the construction companies was the urban action itself that was publicly funded.

\section{Conclusions}

As we have seen in this article, governance, strategic planning and urban competitiveness are far from innocent or innocuous terms. Governance is aimed at normalising the creation of public-private partnerships to implement strategic plans based on urban competitiveness that disregard urban planning standards. In short, the neoliberal model of governance imposes a vision of the city as a business that should concern itself exclusively with multiplying its income 
in a highly competitive global market.

The physical expression of strategic planning and governance is embodied in major urban transformation projects, first launched in several cities in the United States to subsequently become a constant in the world's main cities since the 1990s. In the case of Spain, the two most significant cases of urban renewal in the 1990s, Bilbao and Barcelona, have been taken as a model for the rest of the national urban system in a process of "contagion" that very few cities have been able to withstand. This "fever" has endowed Spain with impressive works throughout the country, although many of these projects have been extravagant, unsustainable and ill-advised (Moix 2010).

Not all cases yielded negative results; in fact, the vast majority of urban projects generated important positive outcomes for the local residents, beyond the strictly economic aspects. It is also logical to assume that the new buildings or transport infrastructures that are still underused at present will yield greater social returns over time. Money has been unwisely invested, but it has not been lost.

The study conducted also shows that a certain demographic and economic level is necessary for the neoliberal model to generate new urban residential areas. Among the analysed cities, there are the cities with the largest demographic size which present more clearly this relationship. Just as the concentration of political power is important. In fact, cities with higher demographic weight have not developed these new residential areas such as Vigo or Cartagena, compared to other less populated but concentrated regional governments, provincial and municipal, as Oviedo, Pamplona, Logroño or Toledo. As for the location, the interior cities analysed generally have a lower urban dynamism than the coastal cities, a fact that can relate to the most significant tourist pressure of the latter.

The economic crisis hit many of these cities extremely hard, with the destruction of hundreds of companies and thousands of jobs and without the possibility of creating a public system of social protection in a context of cuts and funding difficulties. Incomplete urban renewal projects have been rescheduled, slashed or simply scrapped. Spain's specialisation in tourism continues to develop as a direct result of many of these projects, in a context of inter-city competition to attract new tourists and visitors, while the prevailing neoliberal ideology fails to address the needs of the local population.

The only plausible possibility at the beginning of the 21st century for redirecting the development of Spain's cities is to change the model (Somoza Medina 2013). Only in this way we can inhabit cities in which the system of urban government encompasses social empowerment, in which economic parameters are based on intrinsic potential, in which urban planning takes the needs of women, the elderly, youth and children into account, and in which the cultural ecosystem enables the development of talent and creativity without forgetting the roots that have shaped each city's unique personality: in sum, more caring, healthy and sustainable cities, which, while being perhaps less competitive, are certainly happier.

\section{References}

ALCALÁ-SANTAELLA F., DÍAZ ORUETA F., GINÉS SÁNCHEZ X., LOURÉS SEOANE M. L. (2011), Una nueva agenda urbana para las grandes ciudades: crecimiento y competitividad, in: Iglesias M., Martí-Costa M. (eds.), Políticas urbanas en España. Grandes: grandes ciudades, actores y gobiernos locales, Icaria, Barcelona, pp. 307-334.

ASHWORTH G. J., VOOGD H. (1990), Selling the City: marketing approaches in public sector urban planning, Belhaven Press, London.

BLANCO FILLOLA I. (2009), Gobernanza urbana y políticas de regeneración: el caso 
de Barcelona, Revista Española de Ciencia Política 20, 125-146.

BLANCO I., SUBIRATS J. (2012), Políticas urbanas en España: dinámicas de transformación y retos ante la crisis, Geopolítica(s) 3 (1), 15-33.

BORJA J. (2009), Luces y sombras del urbanismo de Barcelona, UOC, Barcelona.

CAPEL H. (2005), El Modelo Barcelona: un examen crítico, del Serbal, Barcelona.

CASELLAS A. (2006), Las limitaciones del «modelo Barcelona». Una lectura desde

Urban Regime Análisis, Documents d'Anàlisi Geogràfica 48, 61-81.

CONEJERO PAZ E. (2005), Globalización, gobernanza local y democracia participativa,

Cuadernos Constitucionales de la Cátedra Fadrique Furió Ceriol 52-53, 13-31.

DAVIES W. K. D., TOWNSHEND I. J. (eds.) (2002), Monitoring Cities: International

Perspectives, Graphcom Printers, Lethbridge.

DELGADO M. (2007), La ciudad mentirosa: fraude y miseria del "modelo Barcelona»,

Los Libros de la Catarata, Barcelona.

ETULAIN J. C. (2008), ¿Gestión promocional o privatización de la gestión urbanística?

Proyecto urbano Puerto Madero, Buenos Aires - Argentina, Bitacora 12 (1), 171-184.

EUROPEAN COMMISSION (2001), La Gobernanza Europea. Un libro blanco, Publicaciones de la Comisión de las Comunidades Europeas, Brussels.

GARCÍA G. O. (2009), La gobernanza: el «buen gobierno» neoliberal, Sistema: Revista de ciencias sociales 212, 15-30.

GONZÁLEZ S. (2007), Trepando por la jerarquía urbana: nuevas formas de gobernanza neoliberal en Europa, UOC Papers. Revista sobre la sociedad del conocimiento 5, 6-12.

GONZÁLEZ CEBALLOS S. (2004), The role of the Guggenheim Museum in the develo-pment of urban entrepreneurial practices in Bilbao, International Journal of Iberian Studies 16 (3), 177-186.

GOVERNMENT OF SPAIN (2013), Ley 27/2013 de racionalización y sostenibilidad de la Administración Local, BOE 312, 106430-106473.

HALL T., HUBBARD P. (eds.) (1998), The Entrepreneurial City: Geographies of Politics, Regime and Representation, Wiley, Chichester.

HARVEY D. (1989), From managerialism to entrepreneurialism: the transformation in urban governance in late capitalism, Geografiska Annaler. Series B, Human Geography 71 (1), 3-17.

JESSOP B. (1997), The entrepreneurial city: re-imaging localities, re-designing economic governance, or re-structuring capital?, in: Jewson N., MacGregor S. (eds.), Realising Cities: New Spatial Divisions and Social Transformation, Routledge, London, pp. 28-41. JOUVE B. (2005), Cuestiones sobre gobernanza urbana, Fundació Cales Pi i Sunyer, Barcelona

KOOIMAN J. (ed.) (1993), Modern governance. New government-society interactions, Sage, London

LOIS GONZÁLEZ R. C. (ed.) (2006), Urban Changes in Different Scales: Systems and Structures, Universidade de Santiago de Compostela, Santiago de Compostela.

LOIS GONZÁLEZ R. C. (2010), Ordenación territorial y competitividad interterritorial: una relación compleja, in: Rodríguez González R. (ed.), Territorio: ordenar para competir, Netbiblo, A Coruña, pp. 29-51. MARTÍNEZ BROUCHOUD M. F. (2010), Gobernanza y legitimidad democrática, Reflexión Política 12 (23), 96-107. MAS SERRA E. (2011), La revitalización del Área Metropolitana de Bilbao: la gestión de Bilbao Ría 2000, aspectos territoriales, Boletín de la AGE 55, 35-57. MÉNDEZ R. (2012), Ciudades y metáforas: sobre el concepto de resiliencia urbana,

Ciudad y Territorio: Estudios territoriales 172, 215-232. MOIX L. (2010), Arquitectura milagrosa, Anagrama, Barcelona.

MURAYAMA Y., DU G. (eds.) (2005), Cities in Global Perspective: Diversity and Tran-sition, Rikkyo University \& IGU, Tokyo. O'DONOGHUE D. P. (ed.) (2014), Urban Transformations: Centres, Peripheries and 
Systems, Ashgate Publisher, Farnham. Glasgow.

PACIONE M. (ed.) (2004), Changing Cities, Strathclyde University Publishing \& IGU,

PAK M. (ed.) (2004), Cities in Transition, University of Ljubljana \& IGU, Ljubljana.

PLAZA B., GÁLVEZ-GÁLVEZ C., GONZÁLEZ-FLORES A., MÁS SERRA E. (2010), Arte y Economía, un matrimonio de conveniencia: el museo Guggenheim en Bilbao, Scripta Nova 14, 323-339.

RHODES R. A. W. (1996), The new governance: Governing without government, Politi-cal Studies 44 (4), 652-667.

RODRÍGUEZ A., MOULAERT F., SWYNGEDOUW E. (2001), Nuevas políticas urba-nas para la revitalización de las ciudades en Europa, Ciudad y Territorio: Estudios territoriales 33 (129), 409-424.

ROJO SALGADO A. (2009), Una aproximación al concepto de gobernanza, in: Rodríguez González R. (ed.), Orde-nación y gobernanza de las áreas urbanas gallegas, Netbiblo, A Coruña, 3-27.

ROSENAU J. N., CZEMPIEL E.-O. (eds.) (1992), Governance without Government: Order and Change in World Politics, Cambridge University Press, New York.

SOMOZA MEDINA J. (2007), Spanish virtual cities: Images, realities and city marketing,

in: Du G. (ed.), Tourism and Urban Transformation, Rykkyo University Press, Tokyo, pp. 93110.

SOMOZA MEDINA J. (2013), Gobernanza urbana, competitividad y procesos de renovación en las ciudades medias españolas, Boletín de la AGE 61, 47-66.

SWYINGEDOUW E. (2005), Governance innovation and the citizen: the Janus Face of Governance-beyond-the-State, Urban Studies 42 (11), 1991-2006.

THEODORE N., PECK J., BRENNER N. (2009), Urbanismo neoliberal: la ciudad y el imperio de los mercados, Temas Sociales 66, 1-12.

VICARIO L., MARTÍNEZ MONJE P. M. (2003), Another 'Guggenheim effect'? The generation of a potentially gentrifiable neigbourhood in Bilbao, Urban Studies 40 (12), 23832400.

Initial submission: 11.01.2016

Revised submission: 14.06 .2016

Final acceptance: 19.06.2016

Correspondence: Department of Geography and Geology, University of León, Av. Facultad de Veterinaria, 25, 24004 León, Spain

Email: jose.somoza@unileon.es 
